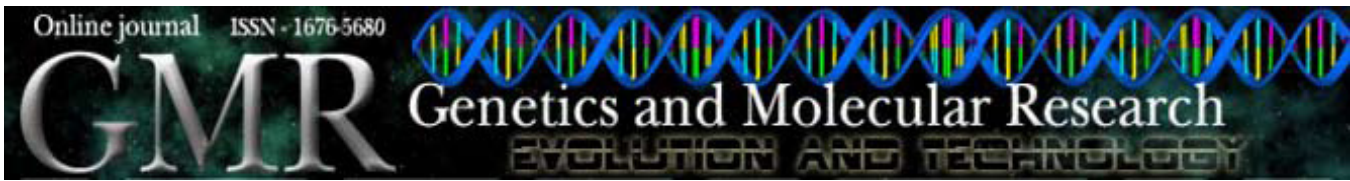

\title{
Climatic and anthropic influence on size and fluctuating asymmetry of Euglossine bees (Hymenoptera, Apidae) in a semideciduous seasonal forest reserve
}

\author{
M.C. Silva ${ }^{1}$, C. Lomônaco ${ }^{2}$, S.C. Augusto ${ }^{2}$ and W.E. Kerr ${ }^{1}$ \\ ${ }^{1}$ Programa de Pós-Gradução em Genética e Bioquímica, \\ Instituto de Genética e Bioquímica, \\ Universidade Federal de Uberlândia, Uberlândia, MG, Brasil \\ ${ }^{2}$ Instituto de Biologia, Universidade Federal de Uberlândia, \\ Uberlândia, MG, Brasil
}

Corresponding author: C. Lomônaco

E-mail: lomonaco@ufu.br.

Genet. Mol. Res. 8 (2): 730-737 (2009)

Received December 12, 2008

Accepted January 26, 2009

Published June 23, 2009

\begin{abstract}
We examined the influence of climate and man on size and fluctuating asymmetry in two species of Euglossine bees collected from a semideciduous forest reserve. Sixty males of each species were collected; four measurements were made of their wings to obtain a multivariable size index and a fluctuating asymmetry index. No significant differences in the size of Eulaema nigrita Lepeletier were found between the areas and seasons. Larger males of Euglossa pleosticta Dressler were collected during the hot and wet season; however, male size did not vary with location. Higher rainfall and a consequent increase in food availability could have influenced the increase in size of E. pleosticta. Bees collected during the hot and wet season at the forest border were more asymmetric than bees collected during the cold and dry season; the latter were found inside the forest. This indicates that climate and anthropic interferences influence the stability of development of E. pleosticta. Consequently, this species
\end{abstract}


could be used as a bioindicator of stress. Apparently, E. nigrita is more resistant to environmental interference.

Key words: Phenotypic plasticity; Development stability; Stress bioindicators; Eulaema nigrita; Euglossa pleosticta

\section{INTRODUCTION}

Environmental factors may cause phenotypic modifications by altering morphological, physiological and behavioral traits; most individual responses to environmental distress are due to phenotypic plasticity (Via and Lande, 1985). This latter term refers to the capability of an organism to alter its phenotypic characteristics without major genetic changes (Scheiner, 1993). Phenotypic plasticity can be considered an important adaptive tool for survival in unstable and heterogeneous environments (Parsons, 1990), including those that vary due to human interference.

Another source of phenotypic variation is developmental noise, which refers to modifications in the normal development program (Markow, 1995). The most common index utilized to describe phenotypic variations caused by developmental noise is fluctuating asymmetry (FA). This latter term is defined as small random deviations from perfect symmetry of a trait in organisms that have bilateral symmetry (Parsons, 1990). Given that expression of both sides of a bilateral trait is due to the same genes, then any asymmetry between the sides is a consequence of environmental disturbance. Therefore, FA could be a good indicator of stress levels or environmental impact (Markow, 1995).

On the other hand, organisms also have the ability to resist genetic and environmental disturbances during their development, through buffering mechanisms, allowing production of a pre-determined phenotype within normal limits of variation in expression. This ability is defined as developmental homeostasis, which is constituted of two components: canalization and developmental stability. Thus, an organism asymmetry may also serve as an indicator of how much of its development is being buffered under stress conditions; because it is inversely correlated with developmental homeostasis, it is frequently used to estimate developmental stability.

Euglossine bees (Hymenoptera, Apidae), found only in the Neotropics (Dressler, 1982), are good indicators of the environmental quality of natural and human-modified ecosystems (Morato, 1994; Peruquetti et al., 1999).

Eulaema nigrita Lepeletier and Euglossa pleosticta Dressler are widely distributed throughout Central America (Ackerman, 1983) and are also found as far as the extreme south of Brazil (Wittmann et al., 1988; Rebêlo and Garófalo, 1997; Nemésio, 2002; Neves and Viana, 2003; Sofia et al., 2004; Nemésio and Silveira, 2006). Contrary to E. pleosticta, E. nigrita is very common in habitats that have suffered human influence (Silveira and Cure, 1993). We examined climatic and anthropic influences on size and FA of these two species of Euglossine bees in a semideciduous forest reserve.

\section{MATERIAL AND METHODS}

Specimens of E. nigrita and E. pleosticta were deposited in the entomological collection of the Laboratório de Ecologia de Insetos of the Universidade Federal de Uberlândia. They were collected monthly for 12 months (from December 1998 to November 1999), in a semideciduous 
forest area $\left(20^{\circ} 46^{\prime} 12^{\prime \prime} \mathrm{S}\right.$ and $47^{\circ} 14^{\prime} 24^{\prime \prime} \mathrm{W}$, altitude between 775 and $\left.836 \mathrm{~m}\right)$. This area is a remnant forest of 49 ha surrounded by an area of 98 ha of unaltered Neotropical Savannah (cerrado).

Bees were collected from two sites: site A, located at the forest border close to the administration building, and site B, approximately $1000 \mathrm{~m}$ apart from site $\mathrm{A}$, located in the interior of the forest fragment.

The climate of this area is between tropical and altitudinal tropical (Awb, accordingly to the Köeppen International System), characterized by the occurrence of two seasons: a humid and hot season from September to April (1400-1550 mm of rain and average temperature varying from $18.4^{\circ}$ to $29^{\circ} \mathrm{C}$ ), and a dry and cold season from May to August ( $35 \mathrm{~mm}$ of rain during the driest month and an average temperature of $23.5^{\circ} \mathrm{C}$ ) (Teixeira et al., 2004).

Sixty males of each species were randomly selected, 30 from the forest border and 30 from the forest interior. Half were collected during the hot and wet season and the other half during the dry and cold season. All individuals had their wings (right and left) detached from the body; these were dry mounted on microscope slides, with a cover slip. Wing veins provide many well-defined morphological landmarks in an essentially plane structure and are commonly used in morphological analysis (Klingenberg and McIntyre, 1998). The slides were scanned and four measurements were made from the images using the computer program Adobe Photoshop, version 6.0. The following wing segments were measured (Figure 1). Each of these segments was measured three times.

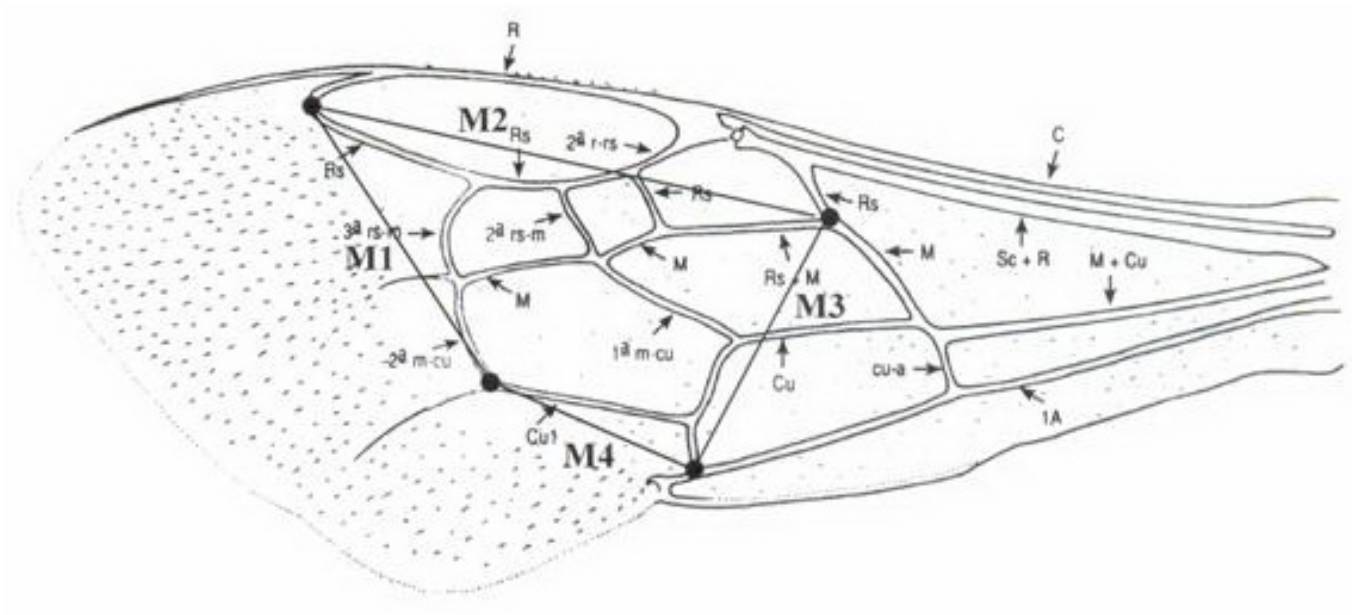

Figure 1. Schematic representation of a bee wing showing the morphological characters of Eulaema nigrita and Euglossa pleosticta measured (adapted from Silveira et al., 2002). For abbreviations, see legend to Table 2.

Measurements were made of both sides in order to evaluate FA, calculated as the mean difference between the right and the left side, i.e., $F A=[(\Sigma|(\mathrm{R}-\mathrm{L})| / \mathrm{n}]$ (Palmer and Strobeck, 1986). A two-factor analysis of variance (ANOVA) was used to determine whether the between-sides variation was significantly larger than the measurement error (Woods et al., 1998; Perfectti and Camacho, 1999). According to Palmer and Strobeck (1986), it is necessary to distinguish FA from other kinds of asymmetry. A $t$-test was performed to determine whether the 
means of the signed right minus left distribution were significantly different from zero. Asymmetry was tested for by looking for significant departures of the right-left frequency distribution from normality using the Kolmogorov-Smirnov test. Size dependence of FA was tested by regressing the unsigned, absolute difference of the right minus left measurements on trait size.

The first of the three measurements was used in the principal component analysis (PCA) in order to obtain a general body size index, estimated by a correlation matrix of the original characters (Manly, 1994). Then, the transformed data (FA and size index) were analyzed with ANOVA to determine the effect of seasonal and anthropic influences (Zar, 1984).

All statistical procedures were performed using the computer software package Systat for Windows, version 9.0 (Willkinson, 1986).

\section{RESULTS}

Since the original morphological variables of E. nigrita and E. pleosticta were significantly correlated, the PCA was considered adequate to estimate the multivariate size index, the score distribution of which was normally adjusted $\left(\mathrm{D}_{\max }=0.078, \mathrm{P}=0.861\right.$ and $\mathrm{D}_{\max }=$ $0.057, \mathrm{P}=0.991$, respectively). The first component, which is the axis that varies most among individuals, explained $82.4 \%$ of the total variance for E. nigrita, and $78.6 \%$ for E. pleosticta morphological data.

Based on two-way ANOVA, there were no significant differences in E. nigrita sizes between areas $(\mathrm{F}=0.251, \mathrm{P}=0.618)$ and seasons $(\mathrm{F}=0.568, \mathrm{P}=0.454)$, nor were there significant interactions between these two factors $(\mathrm{F}=0.413, \mathrm{P}=0.523$; Table 1). There were significant differences in E. pleosticta sizes between seasons $(\mathrm{F}=20.947, \mathrm{P}=0.001)$, but no differences in size were found between areas $(\mathrm{F}=0.109, \mathrm{P}=0.743)$, and there was no significant interaction between areas and seasons $(\mathrm{F}=2.405, \mathrm{P}=0.127$; Table 1).

\begin{tabular}{|c|c|c|c|c|c|}
\hline & SS & d.f. & MS & $\mathrm{F}$ & $\mathrm{P}$ \\
\hline \multicolumn{6}{|l|}{ Eulaema nigrita } \\
\hline Season & 0.586 & 1 & 0.586 & 0.568 & 0.454 \\
\hline Area & 0.259 & 1 & 0.259 & 0.251 & 0.618 \\
\hline Season $\mathrm{x}$ Area & 0.426 & 1 & 0.426 & 0.413 & 0.523 \\
\hline Error & 57.730 & 56 & 1.031 & & \\
\hline \multicolumn{6}{|c|}{ Euglossa pleosticta } \\
\hline Season & 15.542 & 1 & 15.542 & 20.947 & 0.001 \\
\hline Area & 0.081 & 1 & 0.081 & 0.109 & 0.743 \\
\hline Season $x$ Area & 1.784 & 1 & 1.784 & 2.405 & 0.127 \\
\hline Error & 40.808 & 55 & 0.742 & & \\
\hline
\end{tabular}

$\mathrm{SS}=$ sum of squares; d.f. $=$ degrees of freedom; $\mathrm{MS}=$ mean square.

The measurement error of FA was negligible in the analysis of the two species, based on the highly significant side $\mathrm{x}$ individuals effect on two-way ANOVA $(\mathrm{F}=2.470, \mathrm{P}<0.001$ for $\mathrm{M} 1 ; \mathrm{F}=27.968, \mathrm{P}<0.001$ for $\mathrm{M} 2 ; \mathrm{F}=88.040, \mathrm{P}<0.001$ for $\mathrm{M} 3 ; \mathrm{F}=55.115, \mathrm{P}<0.001$ for $\mathrm{M} 4$ of $E$. nigrita, and $\mathrm{F}=3.633, \mathrm{P}<0.001$ for $\mathrm{M} 1 ; \mathrm{F}=4.226, \mathrm{P}<0.001$ for $\mathrm{M} 2 ; \mathrm{F}=1.016, \mathrm{P}$ $<0.001$ for M3; $\mathrm{F}=1.000, \mathrm{P}<0.001$ for M4 of E. pleosticta). All FA distributions were nor- 
mal, and no evidence of antisymmetry was found. No correlations between size and FA were observed and the asymmetry in all traits fluctuated around a mean of zero (Table 2).

\begin{tabular}{|c|c|c|c|c|c|c|c|}
\hline \multirow[t]{2}{*}{ Character } & \multirow[t]{2}{*}{ Mean $\pm \mathrm{SE}(\mathrm{N})$} & \multicolumn{2}{|c|}{ Asymmetry } & \multicolumn{2}{|c|}{ Antisymmetry } & \multicolumn{2}{|c|}{ Correlation } \\
\hline & & $\mathrm{t}$ & $P$ & $\mathrm{D}_{\max }$ & $P$ & $\mathrm{r}$ & $P$ \\
\hline \multicolumn{8}{|c|}{ Eulaema nigrita } \\
\hline M1 & $0.106 \pm 1.171(59)$ & 0.694 & 0.490 & 0.125 & 0.315 & -0.005 & 0.969 \\
\hline M2 & $0.067 \pm 1.436(59)$ & 0.358 & 0.721 & 0.118 & 0.380 & -0.003 & 0.984 \\
\hline M3 & $0.200 \pm 1.722(59)$ & 0.890 & 0.377 & 0.131 & 0.264 & 0.185 & 0.160 \\
\hline M4 & $-0.026 \pm 1.486(59)$ & -0.137 & 0.892 & 0.118 & 0.382 & 0.091 & 0.495 \\
\hline \multicolumn{8}{|c|}{ Euglossa pleosticta } \\
\hline M1 & $-0.122 \pm 0.470(58)$ & -1.997 & 0.051 & 0.074 & 0.280 & 0.051 & 0.704 \\
\hline M2 & $-0.108 \pm 0.462(58)$ & -1.770 & 0.082 & 0.080 & 0.300 & 0.118 & 0.372 \\
\hline M3 & $-0.111 \pm 0.423(58)$ & -1.939 & 0.058 & 0.084 & 0.400 & 0.197 & 0.135 \\
\hline M4 & $-0.069 \pm 0.347(58)$ & -1.502 & 0.139 & 0.085 & 0.351 & 0.183 & 0.166 \\
\hline
\end{tabular}

M1 = distance between the distal extremity of the radial vein (Rs) and the interception of the second medial vein $(2$ nd $\mathrm{M}-\mathrm{Cu})$ with cubital $1(\mathrm{Cu} 1) ; \mathrm{M} 2=$ distance between the distal extremity of Rs to the interception of the medial vein $(\mathrm{M})$ with the proximate portion of the Rs vein; $\mathrm{M} 3$ = distance between the interception of $\mathrm{M}$ with the proximal portion of Rs and the interception of the cubital $(\mathrm{Cu})$ vein with the alar vein $(1 \mathrm{~A})$, and $\mathrm{M} 4=$ distance between the interception of $\mathrm{Cu}$ and $1 \mathrm{~A}$ and the $2 \mathrm{nd} \mathrm{M}-\mathrm{Cu}$.

Based on ANOVA, there were no differences in E. nigrita FA indexes between areas and seasons, and there were no significant interactions between these two factors. For E. pleosticta the interaction of the factors used in two-way ANOVA was significant, but each factor independently did not affect FA (Table 3).

\section{DISCUSSION}

The environment of the forest border area did not affect E. nigrita or E. pleosticta body size, indicating that environmental degradation caused by anthropic influence was not intense. This could also be because the two sites were not distant enough to permit isolation of the feeding areas. According to Sofia and Suzuki (2004) Euglossine males have great vagility and are able to transpose forest fragments separated by distances greater than $1500 \mathrm{~m}$ (Janzen, 1971). For this reason, they are considered to be important Neotropical pollinators, especially for sparse vegetation species (Zucchi et al., 1969; Dressler, 1982), including some orchids that are exclusively visited by them (Williams and Whitten, 1983). Some researchers have investigated the impact of deforestation and forest fragmentation on bee populations; they found a strong decrease in the abundance of individuals (Morato, 1994; Tonhasca Jr. et al., 2003).

Body size of E. nigrita was not affected by season, different from what was found by Peruquetti (2003) in the Atlantic Forest, where variation in body biomass was found between males collected during distinct seasons. However, we did find seasonal variations in E. pleosticta size, which is similar to what was reported by Peruquetti (2003), who found that males collected during the hot and wet season were larger than males collected during the cold and dry season. The higher rainfall levels and the consequent increase in 
Table 3. Two-way ANOVA (considering climatic season and human influence as factors) of the fluctuating asymmetry (FA) of four characters for two species of Euglossine bees collected in a semideciduous seasonal forest reserve in the municipality of Patrocínio Paulista (SP, Brazil) from December 1998 to November 1999.

\begin{tabular}{|c|c|c|c|c|c|c|}
\hline Factor & Characters & SS & d.f. & MS & $\mathrm{F}$ & $\mathrm{P}$ \\
\hline \multicolumn{7}{|c|}{ Eulaema nigrita } \\
\hline \multirow[t]{4}{*}{ FA of M1 } & Area & 0.014 & 1 & 0.014 & 0.020 & 0.887 \\
\hline & Season & 2.390 & 1 & 2.390 & 3.564 & 0.064 \\
\hline & Area*Season & 2.249 & 1 & 2.249 & 3.355 & 0.072 \\
\hline & Error & 36.874 & 55 & 0.670 & & \\
\hline \multirow[t]{4}{*}{ FA of M2 } & Area & 0.626 & 1 & 0.626 & 0.789 & 0.378 \\
\hline & Season & 1.439 & 1 & 1.439 & 1.814 & 0.184 \\
\hline & Area*Season & 0.099 & 1 & 0.099 & 0.124 & 0.726 \\
\hline & Error & 43.642 & 55 & 0.793 & & \\
\hline \multirow[t]{4}{*}{ FA of M3 } & Area & 0.003 & 1 & 0.003 & 0.002 & 0.968 \\
\hline & Season & 5.966 & 1 & 5.966 & 3.539 & 0.065 \\
\hline & Area*Season & 0.003 & 1 & 0.003 & 0.002 & 0.964 \\
\hline & Error & 92.723 & 55 & 1.686 & & \\
\hline \multirow[t]{4}{*}{ FA of M4 } & Area & 0.178 & 1 & 0.178 & 0.193 & 0.662 \\
\hline & Season & 1.148 & 1 & 1.148 & 1.240 & 0.270 \\
\hline & Area*Season & 0.837 & 1 & 0.837 & 0.905 & 0.346 \\
\hline & Error & 50.899 & 55 & 0.925 & & \\
\hline Factor & Characters & SS & d.f. & MS & $\mathrm{F}$ & $\mathrm{P}$ \\
\hline \multicolumn{7}{|c|}{ Euglossa pleosticta } \\
\hline \multirow[t]{4}{*}{ FA of M1 } & Area & 0.094 & 1 & 0.094 & 0.758 & 0.388 \\
\hline & Season & 0.041 & 1 & 0.041 & 0.334 & 0.566 \\
\hline & Area*Season & 0.369 & 1 & 0.369 & 2.985 & 0.090 \\
\hline & Error & 6.800 & 55 & 0.124 & & \\
\hline \multirow[t]{4}{*}{ FA of M2 } & Area & 0.138 & 1 & 0.138 & 0.610 & 0.438 \\
\hline & Season & 0.001 & 1 & 0.001 & 0.001 & 0.974 \\
\hline & Area*Season & 0.139 & 1 & 0.139 & 0.618 & 0.435 \\
\hline & Error & 12.419 & 55 & 0.226 & & \\
\hline \multirow[t]{4}{*}{ FA of M3 } & Area & 0.44 & 1 & 0.44 & 0.370 & 0.545 \\
\hline & Season & 0.360 & 1 & 0.360 & 3.003 & 0.089 \\
\hline & Area*Season & 1.214 & 1 & 1.214 & 0.117 & 0.02 \\
\hline & Error & 6.603 & 55 & 0.120 & & \\
\hline \multirow[t]{4}{*}{ FA of M4 } & Area & 0.039 & 1 & 0.039 & 0.326 & 0.570 \\
\hline & Season & 0.009 & 1 & 0.009 & 0.071 & 0.790 \\
\hline & Area*Season & 0.116 & 1 & 0.116 & 0.968 & 0.330 \\
\hline & Error & 6.573 & 55 & 0.120 & & \\
\hline
\end{tabular}

$\mathrm{SS}=$ sum of squares; d.f. = degrees of freedom; MS = mean square. For M1-M4 abbreviations, see legend to Table 2 .

food availability could have an important effect on the size of E. pleosticta (Crozier and Pamilo, 1996; Peruquetti, 2003).

Body size influences several bee traits related to individual fitness. For females, larger bodies may give greater reproductive success due to better competitive ability and better capacity to do cell provisioning and greater egg production (Tengo and Baur, 1993). For males, greater body size may assure competitive reproductive success and better dispersion ability (Kukuk, 1996). Body size has low heritability; it is generally influenced by environmental and maternal factors, which may cause sufficient variability to affect reproductive capacity (Molumby, 1997). 
The significant interaction area x season, found for E. pleosticta FA of M3, showed that bees collected during the hot and wet season on the forest border were more asymmetric than bees collected during the dry and cold season inside the forest reserve. Consequently, there are indications that climatic and anthropic factors together are influencing the developmental stability of E. pleosticta. The idea that genetic and environmental stress can increase FA makes FA a potential tool to be used for bio-monitoring. A pertinent problem in conservation biology is to find early indicators of stress caused by habitat modification, in order to avoid dangerous or irreversible impacts on the environment (Leary and Allendorf, 1989; Tomkins and Kotiaho, 2001).

Eulaema nigrita was more resistant to environmental changes, since no effects of anthropic and climatic influences were detected. Probably, physiological plasticity buffered the environmental stress conditions, allowing maintenance of the developmental program that is exhibited under optimum or normal conditions (Lomônaco and Germanos, 2001; Silva et al., 2004). The greater resilience of E. nigrita under human influence may be why this species is frequently found in environments that have been modified by man (Silveira and Cure, 1993).

High levels of FA may also have been influenced by endogamy, heterozygosis and recombination, along with environmental effects (Kanegae and Lomônaco, 2003). Though E. nigrita and E. pleosticta are both euglossines, they had different (body size) phenotypic plasticity. Euglossa pleosticta positively responded to temperature and rainfall increase by increasing body size, while $E$. nigrita did not vary with season. They also differed in their ability to buffer environmental disturbance caused by anthropic and climatic influences. E. pleosticta was more susceptible and had higher levels of FA than E. nigrita, and appears to be a more efficient bioindicador of stress. Other research comparing FA levels among populations has also demonstrated the effectiveness of this index as a bioindicator (Leung et al., 2000).

\section{REFERENCES}

Ackerman JD (1983). Diversity and seasonality of male Euglossine bees (Hymenoptera: Apidae) in Central Panama. Ecology 64: 274-283.

Crozier RH and Pamilo P (1996). Evolution of Social Insect Colonies. Sex Allocation and Kin Selection. Oxford University Press, New York.

Dressler RL (1982). Biology of the orchid bees (Euglossini). Annu. Rev. Ecol. Syst. 13: 373-394.

Janzen DH (1971). Euglossine bees as long-distance pollinators of tropical plants. Science 171: 203-205.

Kanegae AP and Lomônaco C (2003). Plasticidade morfológica, reprodutiva e assimetria flutuante de Myzus persicae (Sulzer) (Hemiptera: Aphididae) sob diferentes temperaturas. [Morphological and reproductive plasticity and fluctuating asymmetry of Myzus persicae (Sulzer) (Hemiptera: Aphididae) under different temperatures]. Ecology, Behavior and Bionomics. Neotrop. Entomol. 32: 37-43.

Klingenberg CP and McIntyre GS (1998). Geometric morphometrics of developmental instability: analyzing patterns of fluctuating asymmetry with procrustes methods. Evolution 52: 1363-1375.

Kukuk PF (1996). Male dimorphism in Lasioglossum (chialictus) hemichalceum: the role of larval nutrition. J. Kans. Entomol. Soc. 69: 147-157.

Leary RF and Allendorf FW (1989). Fluctuating asymmetry as an indicator of stress: Implications for conservation biology. Trends Ecol. Evol. 4: 214-217.

Leung B, Forbes MR and Houle D (2000). Fluctuating asymmetry as a bioindicator of stress: comparing efficacy of analyses involving multiple traits. Am. Nat. 155: 101-115.

Lomônaco C and Germanos E (2001). Variações fenotípicas em Musca domestica L. (Diptera: Muscidae) em resposta à competição larval por alimento. Neotrop. Entomol. 30: 223-231.

Manly BFJ (1994). Multivariate Statistical Methods. A Primer. Chapman \& Hall, London.

Markow TA (1995). Evolutionary ecology and developmental instability. Annu. Rev. Entomol. 40: 105-120.

Genetics and Molecular Research 8 (2): $730-737$ (2009)

CFUNPEC-RP www.funpecrp.com.br 
Molumby A (1997). Why make daughter larger? Maternal sex - allocation and sex-dependent selection for body size in a mass-provisioning wasp, Trypoxylon politum. Behav. Ecol. 8: 279-287.

Morato EF (1994). Abundância e riqueza de machos de Euglossini (Hymenoptera: Apidae) em mata de terra firme e áreas de derrubada, nas vizinhanças de Manaus (Brasil). Bol. Mus. Para. Emílio Goeldi Sér. Zool. 10: 95-105.

Nemésio A (2002). Notes on the occurrence of an aberrant coloration in Eulaema nigrita (Hymenoptera: Apidae: Euglossina) in forest fragments in Southeastern Brazil. Lundiana 3: 75-77.

Nemésio A and Silveira SA (2006). First record of Eulaema helvola Moure (Hymenoptera: Apidae: Euglossina) for the State of Minas Gerais: biogeographic and taxonomic implications. Neotrop. Entomol. 35: 418-420.

Neves EL and Viana BF (2003). A Fauna de Abelhas da Subtribo Euglossina (Hymenoptera, Apidae) do Estado da Bahia, Brasil. In: Apoidea Neotropica: Homenagem aos 90 anos de Jesus Santiago Moure (Melo GAR and Alves-dosSantos I, eds.). Editora UNESC, Criciúma, 223-229.

Palmer AR and Strobeck C (1986). Fluctuating asymmetry: measurement, analysis, patterns. Annu. Rev. Ecol. Syst. 17: 391-421. Parsons PA (1990). Fluctuating asymmetry: an epigenetic measure of stress. Biol. Rev. Camb. Philos. Soc. 65: 131-145.

Perfectti F and Camacho JP (1999). Analysis of genotypic differences in developmental stability in Annona cherimola. Evolution 53: 1396-1405.

Peruquetti RC (2003). Variação do tamanho corporal de machos de Eulaema nigrita Lepeletier (Hymenoptera, Apidae, Euglossini). Resposta materna à flutuação de recursos? [Body size variation in males of Eulaema nigrita Lepeletier (Hymenoptera, Apidae, Euglossini). Maternal response to resource fluctuation?]. Rev. Bras. Zool. 20: 207-212.

Peruquetti RC, Campos LAO, Coelho CDP, Abrantes CVM, et al. (1999). Abelhas Euglossini (Apidae) de áreas de Mata Atlântica: abundância, riqueza e aspectos biológicos. Rev. Bras. Zool. 16: 101-118.

Rebêlo JMM and Garófalo CA (1997). Comunidades de machos de Euglossini (Hymenoptera: Apidae) em matas semidecíduas do Nordeste do Estado de São Paulo. [Communities of male Euglossine bees (Hymenoptera: Apidae) in semideciduous forests from Northeastern São Paulo State]. Ann. Soc. Entomol. 26: 243-255.

Scheiner SM (1993). Genetics and evolution of phenotypic plasticity. Annu. Rev. Ecol. Entomol. 24: 35-68.

Silva JJ, Mendes J and Lomônaco C (2004). Developmental stress by diflubenzuron in Haematobia irritans (L.) (Diptera: Muscidae). Neotrop. Entomol. 33: 249-253.

Silveira FA and Cure JR (1993). High-altitude bee fauna of Southeastern Brazil: implications for biogeographic patterns (Hymenoptera: Apoidea). Stud. Neotrop. Fauna Environ. 28: 47-55.

Silveira FA, Melo GAR and Almeida EAB (2002). Abelhas Brasileiras: Sistemática e Identificação. PROBIO, Belo Horizonte.

Sofia SH and Suzuki KM (2004). Comunidades de machos de abelhas Euglossina (Hymenoptera: Apidae) em fragmentos florestais no sul do Brasil. [Communities of Euglossine males (Hymenoptera: Apidae) in forest fragments from southern Brazil]. Neotrop. Entomol. 33: 693-702.

Sofia SH, Santos AM and Silva CRM (2004). Euglossine bees (Hymenoptera, Apidae) in a remnant of Atlantic Forest in Paraná State, Brazil. Iheringia Sér. Zool. 94: 217-222.

Teixeira MIJG, Araújo ARB, Valeri SV and Rodrigues RR (2004). Florística e fitossociologia de área de cerrado S.S. no município de Patrocínio Paulista, nordeste do Estado de São Paulo. [Floristic and phytosociology of area of cerrado "scritu sensu", in northeast region of São Paulo State, Brazil]. Bragantia 63: 1-11.

Tengo J and Baur B (1993). Number and size of oocites in relation to body size and time of day in the kleptoparasite bee Nomada lathburiana (Hymenoptera: Anthophoridae). Entomol. Gen. 18: 19-24.

Tomkins JL and Kotiaho JS (2001). Fluctuating Asymmtry. In: Encyclopedia of Life Sciences. Macmillan Publishers Ltd., Nature Publishing Group, London, 1-5.

Tonhasca Jr A, Albuquerque GSA and Blackmer JL (2003). Dispersal of Euglossine bees between fragments of the Brazilian Atlantic Forest. J. Trop. Ecol. 19: 99-102.

Via S and Lande R (1985). Genotype-environment interaction and the evolution of phenotypic plasticity. Evolution 39: 505-522.

Williams NH and Whitten WM (1983). Orchid floral fragrance and male Euglossine bee. Methods and advances in the last sesquidecade. Biol. Bull. 164: 355-395.

Willkinson L (1986). SYSTAT: The System for Statistics. II SYSTAT Inc., Evanston.

Wittmann D, Hoffmann M and Scholz E (1988). Southern distributional limits of Euglossine bees in Brazil linked to habitats of the Atlantic and subtropical rain forest (Hymenoptera: Apidae: Euglossini). Entomol. Gen. 14: 53-60.

Woods RE, Hercus MJ and Hoffmann AA (1998). Estimating the heritability of fluctuating asymmetry in field Drosophila. Evolution 52: 816-824.

Zar JH (1984). Biostatistical Analysis. Prentice Hall, New Jersey.

Zucchi R, Camargo JMF and Sakagami SF (1969). Biological observations on a Neotropical bee, Eulaema nigrita, with a review on the biology of Euglossinae (Hymenoptera: Apoidea): A comparative study. J. Fac. Sci. Hokkaido Uni. Ser. 6 Zool. 17: 271-380. 